\title{
EFEK TERAPI MUSIK UNTUK MENURUNKAN TEKANAN DARAH PADA PASIEN HIPERTENSI DI DESA TARAMAN SRAGEN JAWA TENGAH
}

\author{
Oleh : \\ Diyono $^{1}$, Putri Mawarni ${ }^{2}$
}

\begin{abstract}
Background: Hypertension is often called the "silent killer" (killer stealth), because often people with hypertension chronically ill without experiencing clinically overt disease. The prevalence of hypertension in Indonesia reached $31.7 \%$ of the population aged 18 years and above. Of that amount, $60 \%$ of hypertension patients have complications of stroke. While the rest of developing heart disease, kidney failure, and blindness. Hypertension is the third leading cause of death after stroke and tuberculosis, accounted for $6.8 \%$ of the proportion of causes of death in all age groups in Indonesia. Management of hypertension can be nonpharmacological therapy such is music therapy Objective: (1) determine the classification of hypertension in the village Taraman Sragen (2) determine the blood pressure in patients with hypertension in the village Taraman Sragen before given music therapy. (3) determine the blood pressure in patients with hypertension in the Village Sragen Taraman after the given music therapy (4) the effect of music therapy on reduction of blood pressure in patients with hypertension.

Methode: This type of research is analytic quasi - experimental design Research Subjects: The study population was patients with hypertension in the village of Taraman Sragen. A large population of 33 people who suffer from hypertension. Be obtained through the total sampling technique respondents who met the inclusion criteria as much as 20 respondents. Effect of music therapy was analysed by Paired T-Test with SPSS18.

Results: (1) Classification of systolic hypertension is lightweight category $75 \%$, the category was $25 \%$, and the average category mild hypertension (2) The classification of hypertensive diastolic including mild $20 \%$, moderate $55 \%$, severe $25 \%$, and the average including moderate hypertension category (3) blood pressure before being given music therapy for systolic average 150.5 categorized as mild and diastolic average 100.5 including medium category (4) systolic blood pressure after being given music therapy average 130 (high normal category) and for diastolic average 88 including the normal category (5) Results of statistical test with Paired T-Test showed that a significant effect of music therapy in decrease or reduced sistolic and diastolic blood pressure (sig = $0,000)$
\end{abstract}

Conclusion: Music therapy significant influence in decrease blood pressure (sig $=0,000)$.

Keywords: Music Therapy and Blood Pressure

\section{PENDAHULUAN}

Hipertensi sering disebut sebagai "silent killer" (pembunuh siluman), karena seringkali penderita hipertensi bertahun-tahun tanpa merasakan sesuatu gangguan atau gejala. Tanpa disadari penderita mengalami komplikasi pada organorgan vital seperti jantung, otak ataupun ginjal. (Triyanto, 2014) Menurut Riskesda (Riset Kesehatan Daerah), sebagaimana dikutip oleh Triyanto (2014), prevalensi hipertensi di Indonesia mencapai 
$31,7 \%$ dari populasi usia 18 tahun ke atas. Dari jumlah itu, $60 \%$ penderita hipertensi mengalami komplikasi stroke. Sedangkan sisanya mengalami penyakit jantung, gagal ginjal, dan kebutaan. Hipertensi sebagai penyebab kematian ke-3 setelah stroke dan tuberculosis, jumlahnya mencapai $6,8 \%$ dari proporsi penyebab kematian pada semua umur di Indonesia.

Secara garis besar, pengobatan hipertensi dibagi dalam dua kategori, yaitu pengobatan non-farmakologis dan pengobatan farmakologis. Pengobatan non-farmakologis merupakan pengobatan tanpa obatobatan yang diterapkan pada penderita hipertensi. Pengobatan farmakologis dilakukan pada hipertensi dengan tekanan darah $140 / 90 \mathrm{mmHg}$ atau lebih. (Junaidi, 2010)

Salah satu penanganan nonfarmakologis yang dapat diterapkan untuk menurunkan tekanan darah pada penderita hipertensi adalah terapi musik. Menurut Potter (2005) sebagaimana dikutip oleh Triyanto (2014), terapi musik adalah teknik yang digunakan untuk penyembuhan suatu penyakit dengan menggunakan bunyi atau irama tertentu. Jenis musik yang digunakan dalam terapi musik dapat disesuaikan dengan keinginan, misalnya musik klasik, instrumentalia, musik berirama santai, orchestra dan musik modern lainnya.

Dari latar belakang yang diuraikan diatas maka rumusan masalah pada penelitian ini adalah "Apakah ada pengaruh terapi musik terhadap penurunan tekanan darah pada penderita hipertensi di Desa Taraman Sragen tahun 2015".

\section{TUJUAN PENELITIAN}

Tujuan umum penelitian ini adalah untuk mengetahui pengaruh terapi musik terhadap penurunan tekanan darah pada penderita hipertensi di Desa Taraman Sragen. Adapun tujuan khusus adalah untuk mengetahui klasifikasi hipertensi, tekanan darah pada penderita hipertensi di Desa Taraman Sragen sebelum diberikan terapi musik, dan mengetahui tekanan darah pada penderita hipertensi di Desa Taraman Sragen sesudah diberikan terapi musik.

\section{METODE PENELITIAN}

Penelitian ini merupakan penelitian eksperimen semu atau quasi eksperiment dengan rancangan pre post eksperimental, untuk mengetahui pengaruh pemberian terapi musik terhadap penurunan tekanan darah pada penderita hipertensi. Pengaruh atau efek dari terapi musik diketahui dengan cara membandingkan tekanan darah sistolik dan diastolik sebelum dan setelah diberi terapi musik. Populasi penelitian ini adalah 33 warga masyarakat Desa Taraman Sragen yang menderita hipertensi. Sampel atau responden yang peneliti peroleh berdasar kriteria inklusi dan ekslusi adalah sebanyak 20 responden. Hal ini terjadi karena ada beberapa responden yang mengalami hipertensi, tetapi sedang mengkonsumsi obat penurun tekanan darah, usia lebih dari 70 tahun dan ada yang mengalami gangguan pendengaran sehingga tidak masuk sebagai kriteria inklusi sebagai responden. Data yang sudah terkumpul akan dianalisa menggunakan paired $t$ test dengan bantuan program SPSS for Windows Seri 18 , dengan tingkat signifikansi $p$ $=0,05$. 


\section{HASIL PENELITIAN}

Penelitian telah dilaksanakan pada tanggal 14 Maret 2015 sampai dengan 05 April 2015, dilaksanakan di Desa Taraman Kecamatan Sidoharjo Kabupaten Sragen Propinsi Jawa Tengah.

\section{Karakteristik Responden}

1. Berdasarkan Jenis Kelamin

Tabel 1. Distribusi Frekuensi

Penderita Hipertensi

Berdasarkan Jenis Kelamin

\begin{tabular}{lcc}
\hline Jenis Kelamin & $\mathbf{f}$ & $\mathbf{( \% )}$ \\
\hline Laki-laki & 9 & 45 \\
\hline Perempuan & 11 & 55 \\
\hline Jumlah & 20 & 100 \\
\hline
\end{tabular}

Tabel 1 menunjukkan bahwa hipertensi lebih banyak dialami oleh responden perempuan yaitu 11 atau $55,00 \%$ dibanding laki laki yang hanya sebesar $45,00 \%$ atau 9 responden.

2. Karakteristik berdasarkan kelompok umur

Karakterisitik responden berdasar usia, hipertensi paling banyak diderita pada kelompok warga usia 46 - 50 tahun sebanyak 7 responden atau $35,00 \%$ dan yang paling sedikit adalah pada kelompok umur 40 - 45 tahun yaitu 3 responden atau $15,00 \%$.

Tabel 2. Distribusi Frekuensi Penderita Hipertensi Berdasarkan Usia

\begin{tabular}{ccc}
\hline $\begin{array}{c}\text { Kelompok } \\
\text { Umur (th) }\end{array}$ & $\mathbf{f}$ & $\mathbf{( \% )}$ \\
\hline $40-45$ & 3 & 15 \\
\hline $46-50$ & 7 & 35 \\
\hline $51-55$ & 5 & 25 \\
\hline $56-60$ & 5 & 25 \\
\hline Jumlah & 20 & 100 \\
\hline
\end{tabular}

3. Karakteristik responden berdasarkan status riwayat atau lamanya hipertensi

Tabel 3. Distribusi Frekuensi Penderita Hipertensi Berdasarkan Riwayat Lamanya Hipertensi

\begin{tabular}{lcc}
\hline $\begin{array}{c}\text { Lamanya } \\
\text { Hipertensi }\end{array}$ & $\mathbf{f}$ & $\mathbf{( \% )}$ \\
\hline Tidak Tahu & 13 & 65 \\
\hline$<1$ tahun & 3 & 15 \\
\hline $1-5$ tahun & 2 & 10 \\
\hline $6-10$ tahun & 0 & 0 \\
\hline$>10$ tahun & 2 & 20 \\
\hline Jumlah & 20 & 100 \\
\hline
\end{tabular}

Tabel 3 memberikan informasi bahwa ternyata berdasarkan riwayat lamanya hipertensi yang dialami responden, mayoritas atau $65 \%$ atau 13 responden mengatakan tidak tahu, dan yang paling sedikit adalah pada kategori lama hipertensi $6-10$ tahun yaitu $0 \%$.

4. Karakteristik responden berdasarkan riwayat keluarga atau keturunan

Berdasar riwayat atau keturunan keluarga dengan hipertensi menunjukkan bahwa ternyata paling banyak hanya $20 \%$ atau 4 responden yang mengatakan ada riwayat keluarga dengan hipertensi sedangkan sisanya 16 atau $80 \%$ responden tidak mempunyai riwayat keluarga dengan hipertensi.

Tabel 4. Distribusi Frekuensi Penderita Berdasarkan Riwayat Keluarga atau Keturunan

\begin{tabular}{lcc}
\hline $\begin{array}{c}\text { Riwayat } \\
\text { Keturunan }\end{array}$ & F & (\%) \\
\hline Ada & 4 & 20 \\
\hline Tidak Ada & 16 & 80 \\
\hline Jumlah & 20 & 100 \\
\hline
\end{tabular}


5. Karakteristik responden berdasarkan riwayat kebiasaan hidup atau hobi

Tabel 5. Distribusi Frekuensi Penderita Hipertensi Berdasarkan Riwayat Kebiasaan Hidup (Hobi)

\begin{tabular}{lcc}
\hline $\begin{array}{c}\text { Kebiasaan } \\
\text { Hidup (Hobi) }\end{array}$ & $\mathbf{f}$ & $\mathbf{( \% )}$ \\
\hline Merokok & 2 & 10 \\
\hline Begadang & 3 & 15 \\
\hline Positip (Sehat) & 4 & 20 \\
\hline Tidak punya & 11 & 55 \\
\hline Jumlah & 20 & 100 \\
\hline
\end{tabular}

Tabel 5 menunjukkan bahwa berdasar riwayat kebiasaan hidup atau hobi yang dimiliki oleh responden paling banyak adalah tidak punya hobi yang spesifik yaitu 11 responden atau 55\% dan yang paling sedikit adalah kebiasaan merokok sebanyak 2 atau $10 \%$ responden.

6. Karakteristik responden berdasarkan riwayat pengobatan atau terapi

Tabel 6. Distribusi Frekuensi Penderita Hipertensi Berdasarkan Riwayat Pengobatan atau Terapi

\begin{tabular}{lcc}
\hline Pengobatan/Terapi & $\mathbf{f}$ & $\mathbf{( \% )}$ \\
\hline Dibiarkan & 14 & 70 \\
\hline Obat Medis & 2 & 10 \\
\hline Herbal & 2 & 10 \\
\hline Kombinasi & 2 & 10 \\
\hline Jumlah & 20 & 100 \\
\hline
\end{tabular}

Tabel 6 memperlihatkan bahwa berdasar pengobatan atau terapi hipertensi, paling banyak hanya dibiarkan yaitu 14 atau $70 \%$ responden dan sisanya diberikan terapi obat medis, herbal, dan kombinasi obat medis dan herbal masing - masing sebanyak 2 atau $10 \%$ responden.

\section{Hasil Penelitian}

1. Tekanan darah sistolik sebelum diberikan terapi musik

Tabel 7. Distribusi Frekuensi Takanan Darah Sistolik Sebelum Diberi Terapi Musik

\begin{tabular}{lcc}
\hline \multicolumn{1}{c}{ Kategori } & $\mathbf{f}$ & $\mathbf{( \% )}$ \\
\hline Normal & 0 & 0 \\
\hline Normal Tinggi & 0 & 0 \\
\hline Ringan & 15 & 75 \\
\hline Sedang & 5 & 25 \\
\hline Berat & 0 & 0 \\
\hline Sangat Berat & 0 & 0 \\
\hline Jumlah & 20 & 100 \\
\hline
\end{tabular}

Hasil analisa univariat sebagai berikut :

\begin{tabular}{ccccc}
\hline Mean & Median & Max & Min & Std \\
\hline 150,5 & 150 & 160 & 140 & 6,86 \\
\hline
\end{tabular}

2. Tekanan darah diastolik sebelum diberi terapi musik

Tabel 8. Distribusi Frekuensi Tekanan Darah Diastolik Sebelum Diberi Terapi Musik

\begin{tabular}{lcc}
\hline Kategori & $\mathbf{f}$ & $\mathbf{( \% )}$ \\
\hline Normal & 0 & 0 \\
\hline $\begin{array}{l}\text { Normal } \\
\text { Tinggi }\end{array}$ & 0 & 0 \\
\hline Ringan & 4 & 20 \\
\hline Sedang & 11 & 55 \\
\hline Berat & 5 & 25 \\
\hline Sangat Berat & 0 & 0 \\
\hline Jumlah & 20 & 100 \\
\hline
\end{tabular}

Hasil analisa univariat sebagai berikut :

\begin{tabular}{ccccc}
\hline Mean & Median & Max & Min & Std \\
\hline 100,5 & 100 & 110 & 90 & 6,86 \\
\hline
\end{tabular}


3. Tekanan darah sistolik setelah diberi terapi musik

Tabel 9. Distribusi Frekuensi Tekanan Darah Sistolik Setelah Diberi Terapi Musik

\begin{tabular}{lcc}
\hline \multicolumn{1}{c}{ Kategori } & $\mathbf{f}$ & $\mathbf{( \% )}$ \\
\hline Normal & 15 & 75 \\
\hline Normal Tinggi & 5 & 25 \\
\hline Ringan & 0 & 0 \\
\hline Sedang & 0 & 0 \\
\hline Berat & 0 & 0 \\
\hline Sangat Berat & 0 & 0 \\
\hline Jumlah & 20 & 100 \\
\hline
\end{tabular}

Hasil Univariat sebagai berikut :

\begin{tabular}{ccccc}
\hline Mean & Median & Max & Min & Std \\
\hline 130 & 130 & 150 & 110 & 11,25 \\
\hline
\end{tabular}

4. Tekanan darah diastolik setelah terapi musik

Tabel 10. Distribusi Frekuensi Tekanan Darah Diastolik Setelah Diberi Terapi Musik

\begin{tabular}{lcc}
\hline \multicolumn{1}{c}{ Kategori } & $\mathbf{f}$ & $\mathbf{( \% )}$ \\
\hline Normal & 9 & 45 \\
\hline Normal Tinggi & 0 & 0 \\
\hline Ringan & 6 & 30 \\
\hline Sedang & 5 & 25 \\
\hline Berat & 0 & 0 \\
\hline Sangat Berat & 0 & 0 \\
\hline Jumlah & 20 & 100 \\
\hline
\end{tabular}

Hasil analisis univariat sebagai berikut :

\begin{tabular}{ccccc}
\hline Mean & Med & Max & Min & Std \\
\hline 88 & 90 & 100 & 80 & 8,34 \\
\hline
\end{tabular}

Tabel 11. Tabel Perubahan Tekanan Darah Sebelum dan Sesudah Terapi Musik

\begin{tabular}{|c|c|c|c|c|}
\hline \multirow{2}{*}{$\begin{array}{c}\text { Perubahan } \\
\text { tekanan } \\
\text { darah }\end{array}$} & \multicolumn{2}{|c|}{ Sistol } & \multicolumn{2}{|c|}{ Diastol } \\
\hline & $f$ & $\%$ & $f$ & $\%$ \\
\hline Turun & 19 & & 15 & 15 \\
\hline & & & 4 & 20 \\
\hline Mening & 0 & 0 & 1 & 5 \\
\hline
\end{tabular}

5. Pengaruh terapi musik terhadap tekanan darah

Test normalitas data

Hasil uji normalitas data dengan Kolmogorov Smirnov test, menunjukkan nilai signifikansi (sig) menunjukkan semuanya lebih besar dari 0,05 sehingga dapat menggunakan statistik parametri

\section{Paired samples correlations}

\begin{tabular}{cc}
\hline TD & Sig \\
\hline $\begin{array}{c}\text { Sistole pre dan sistoel } \\
\text { post terapi musik }\end{array}$ & 0,73 \\
\hline $\begin{array}{c}\text { Diastole pre dan } \\
\text { diastole post terapi } \\
\text { musik }\end{array}$ & 0,93 \\
\hline
\end{tabular}

Nilai paired samples correlations tersebut menunjukkan sig > 0,05 yang berarti tidak ada pengaruh atau korelasi antara tekanan darah sebelum dan sesudah dilakukan terapi musik. Hasil tersebut menunjukkan tekanan darah sebelum dan sesudah terapi musik tidak saling berhubungan atau ada perbedaan.

Paired Samples T-Test tekanan darah sistole

\begin{tabular}{ccccc}
\hline \multicolumn{2}{c}{ Mean } & & \\
\cline { 1 - 3 } $\begin{array}{c}\text { Sistole } \\
\text { Pre }\end{array}$ & $\begin{array}{c}\text { Sistole } \\
\text { Post }\end{array}$ & & Sig \\
\hline 150,50 & 130,00 & 8,731 & 0,000 \\
\hline
\end{tabular}

Hasil tersebut menunjukkan terdapat perbedaan yang signifikan nilai tekanan darah sistolik antara sebelum dan sesudah dilakukan terapi musik, dimana nilai $t=8,731>$ dari nilai $\mathrm{t}$ tabel dengan sig $=0,000$. 
Paired T-Test untuk tekanan darah sistolik antara sebelum dan setelah dilakukan terapi musik adalah sig $=0,000$, demikian juga utuk tekanan darah diastolik juga menunjukkan nilai sig $=0,000$. Hasil tersebut juga dikuatkan dengan nilai $t$ lebih besar dari $t$ tabel yang berarti terdapat perbedaaan nilai rata - rata antara sebelum dan sesudah diberikan perlakukan yaitu terapi musik. Disamping itu nilai Paired samples correlations untuk tekanan darah sistolik sebelum dan setelah perlakuan $(0,73)$ dan tekanan darah diastolik $(0,93)$ adalah lebih besar dari 0,05 yang berarti nilai tekanan darah sebelum dan setelah diberi perlakuan adalah berbeda atau tidak ada hubungan.

Dengan nilai rata - rata (means) tekanan darah sistolik setelah perlakukan sebesar 130,00 lebih kecil dari nilai rata - rata sebelum diberi terapi musik yaitu 150,50 menunjukkan bahwa terapi musik efektif untuk menurunkan tekanan darah sistolik. Tekanan darah sistol adalah suara yang terdengar saat pengukuran dengan stetoskop yang muncul saat menutupnya katub trikuspidalis dan katub bikuspidalis jantung. (Pearce, 2010) Demikian juga untuk nilai tekanan darah diastol menujukkan nilai rata - rata setelah diberi perlakuan dengan terapi musik lebih rendah daripada sebelum diberi terapi musik yaitu dari 100,50 turun menjadi 88,00. Tekanan darah diastol adalah bunyi yag muncul pada saat katub aorta dan pulmonal menutup secara bersamaan. (Pearce, 2010).

Hasil analisa univariat juga mendukung kesimpulan di atas. Nilai median (nilai tengah) setelah diberikan terapi musik baik sistolik maupun diastolik juga menunjukkan penurunan, yaitu untuk sistolik dari 150,5 turun menjadi 130, demikian juga diastolik juga turun dari 100,5 menjadi 88. Demikian juga untuk nilai maksimal dan minimal tekanan darah juga mengalami penurunan untuk sistolikdari 160 dan 140 menurun menjadi 150 dan 110. Hal ini juga terjadi pada tekanan diastolik dari 110 dan 90 menurun menjadi 100 dan 80 . Hasil analisis univariat tersebut memberikan bukti bahwa tekanan darah pada responden setelah diberi perlakuan mengalami penurunan atau lebih rendah dari sebelum diberi perlakuan.

Hipertensi atau tekanan darah tinggi adalah suatu peningkatan abnormal tekanan darah arteri secara terus-menerus lebih dari satu periode dengan tekanan darah sistolik $\geq 140 \mathrm{mmHg}$ dan atau tekanan darah diastolik $\geq 90$ mmHg. (Udjianti, 2010) Secara fisiologis tekanan darah dipengaruhi oleh 2 (dua) faktor utama yaitu curah jantung (cardiac output) dan tahanan pembuluh darah. Tekanan darah akan naik jika terjadi kenaikan salah satu atau dari kedua komponen tersebut. (Pearce, 2010)

Salah satu terapi yang mulai dikembangkan adalah terapi musik. Hasil penelitian ini membuktikan secara empirik bahwa musik merupakan salah satu terapi yang cukup efektif dalam menurunkan tekanan darah. Menurut Aizid (2011) terapi adalah musik sebagai suatu usaha yang berupa bantuan dari proses terencana dengan menggunakan musik sebagai media penyembuhan bagi anak yang mengalami hambatan dalam masa pertumbuhan dan perkembangannya, penyembuhan bagi para 
penderita penyakit lansia, stroke, atau stress dan mencerdaskan otak. Pada penelitian ini penderita hipertensi secara teratur dan terencana diminta atau diberikan terapi musik berupa musik tradisional yaitu musik campursari atau keroncong sesuai yang disukai responden. Pada tahap awal peneliti mengukur tekanan dan mencatat tekanan darah responden. Kemudian secara mandiri ataupun dengan bantuan pengawasan dari keluarga responden diminta untuk mendengarkan musik campur sari atau keroncong dengan tape recorder atau $C D$ Player selama 10 - 15 menit sebanyak 2 kali pada waktu longgar atau istirahat. Kegiatan ini dilakukan selama 6 (enam) hari berturut - turut. Selama terapi tersebut responden tidak mengkonsumsi obat penurun tekanan darah baik dari medis maupun herbal dengan pola makan biasa sehari - hari atau tidak diet. Setelah tindakan tersebut maka peneliti kembali melakukan pengukuran tekanan darah dari responden. Hasil pengukuran menunjukkan nilai rata - rata tekanan darah pasien setelah perlakuan lebih rendah daripada sebelum perlakukan.

Menurut Setyoadi dan Kushariyadi (2011), musik tradisional seperti bunyi tambur, genta, dan gamelan jawa dapat memberi ketenangan hidup dan psikis. Tekanan darah dapat mengalami peningkatan jika terjadi peningkatan denyut jantung (heart rate) dan penyempitan pembuluh darah. Peningkatan denyut jantung dapat meningkatkan curah jantung, sedangkan penyempitan pembuluh darah dapat meningktakan tekanan atau tahanan pembuluh darah. Seperti yang disampaikan Pearce (2010), jika salah satu atau kedua faktor tersebut ada maka akan terjadi peningkatan tekanan darah. Terapi musik dapat memberikan suasana rileks dan damai sehingga dapat membuat denyut jantung normal dan tahanan pembuluh darah juga normal, sehingga tekanan darah dapat menurun menjadi normal. Musik juga dapat menimbulkan reaksi psikologis yang dapat mengubah suasana hati dan kondisi emosi, yang dapat membuat pendengarnya relaks sehingga dapat menghilangkan stres, mengatasi kecemasan, memperbaiki mood, dan menumbuhkan kesadaran spiritual. (Aizid, 2011)

Hasil penelitian ini juga sesuai dengan penelitian terdahulu dari Murni (2010) yang melakukan penelitian dengan judul efektifitas terapi musik klasik dalam menurunkan tekanan darah pada penderita hipertensi di Desa Pandau Jaya, wilayah kerja Puskesmas Simpang Tiga Marpoyan. Dengan jumlah sampel 30 orang, dimana 15 orang sebagai kelompok eksperimen dan 15 kelompok kontrol, dan dianalisa menggunakan dependent dan independent $T$ test, menunjukkan rata-rata tekanan darah arteri (MAP) sebelum dan setelah terapi adalah 118,6 dan 112,3 , dan nilai $p$ value $=0,000$ yang berarti terjadi penurunan tekanan darah setelah diberikan intervensi. Perbedaan penelitian ini dengan penelitian dari Murni (2010) terletak pada komponen yang dianalisis yaitu MAP (Mean Arterial Pressure) dan adanya kelompok kontrol sebagai pembanding dari kelompok perlakuan.

Penelitian lain yang juga memberikan hasil yang sama dengan penelitian ini adalah penelitian Suherly, Ismonah, dan 
Meikawati (2013). Penelitian dengan judul perbedaan tekanan darah pada pasien hipertensi sebelum dan sesudah pemberian terapi musik klasik di RSUD Tugurejo Semarang. Dengan rancangan one group pre test post test pada 28 responden dengan teknik accidental sampling, menunjukkan hasil uji Wilcoxon untuk tekanan darah sistolik dan diastolik adalah $\mathrm{p}=$ $0,000(<0,05) \quad$ yang berarti terdapat perbedaan tekanan darah sistolik dan diastolik pada pasien sebelum dan sesudah pemberian terapi musik klasik. Komponen yang membedakan dari penelitian ini dengan penelitian Suherly, Ismonah, dan Meikawati (2013) adalah pada jenis uji statistik yaitu menggunakan uji Wilcoxon.

Berdasar hasil peneltian tersebut memberikan bukti secara empirik dan ilmiah bahwa terapi musik dapat secara efektif menurunkan tekanan darah. Untuk itu terapi musik dapat direkomendasikan sebagai salah satu alternatif perawatan pada pasien yang mengalami hipertensi.

\section{KESIMPULAN}

1. Klasifikasi hipertensi berdasar tekanan darah sistolik adalah kategori ringan $75 \%$, kategori sedang $25 \%$, dengan rata - rata termasuk kategori hipertensi ringan.

2. Klasifikasi hipertensi berdasar tekanan darah diastolik yang termasuk ringan 20\%, sedang $55 \%$, berat $25 \%$, dengan rata rata termasuk kategori hipertensi sedang.

3. Tekanan darah sebelum diberi terapi musik untuk sistolik rata rata 150,5 (ringan) dan diastolik rata - rata 100,5 termasuk kategori sedang.

4. Tekanan darah setelah diberikan terapi musik untuk sistolik rata - rata 130 (normal tinggi) dan untuk diastolik rata - rata 88 termasuk kategori normal tinggi.

5. Hasil uji statistik dengan Paired TTes menunjukkan bahwa terapi musik berpengaruh secara signifikan dalam menurunkan tekanan darah $(p=0,000)$.

\section{SARAN}

1. Untuk masyarakat dapat mempertimbangkan untuk melakukan terapi musik dalam upaya menurunkan tekanan darah.

2. Untuk perawat hendaknya terapi musik dapat dijadikan sebagai salah satu terapi alternatif dalam perawatan pasien hipertensi.

3. Bagi institusi pendidikan hendaknya memasukkan terapi musik dalam kurikulum pembelajaran pada mahasiswa.

4. Bagi peneliti selanjutnya hasil penelitian ini dapat digunakan sebagai data awal dalam pengembangan penelitian selanjutnya tentang manfaat terapi musik dan perawatan hipertensi.

\section{DAFTAR PUSTAKA}

Aizid, Rizem. Sehat dan Cerdas dengan Terapi Musik. Yogyakarta: Laksana, 2011.

Dalimartha, Setiawan, et al. Care Your Self Hipertensi. Jakarta : Penebar Plus+, 2008.

Hidayat, A. Aziz Alimul. Riset Keperawatan dan Teknik Penulisan IImiah. Jakarta: Salemba Medika, 2008.

\section{Metode}

Penelitian Keperawatan dan Teknik Analisis Data. Jakarta: Salemba Medika, 2009.

Junaidi, Iskandar. Hipertensi. Jakarta: PT Bhuana IImu Populer, 2010. 
Muttaqin, Arif. Pengantar Asuhan Keperawatan Klien dengan Gangguan Sistem Kardiovaskular: Pengantar dan Teori. Jakarta : Salemba Medika, 2009.

Natalina, Dian. Terapi Musik Bidang Keperawatan. Jakarta: Mitra Wacana Media, 2013.

Pearce, Evelyn. Anatomi dan Fisiologi untuk Paramedis. Alih Bahasa Sri Yuliani Handoyo. Jakarta: Gramedia, 2010.

Price, Sylvia Anderson and Lorraine Mc Carty Wilson. Patofissiologi: Konsep Klinis Proses Penyakit. Edisi 6 Volume 2. Jakarta: EGC. 2005 .

Setyoadi dan Kushariyadi. Terapi Modalitas Keperawatan pada Klien Psikogeriatrik. Jakarta: Salemba Medika, 2011.

Smeltzer, Suzanne C. Dan Brenda G. Bare. Keperawatan Medikal Bedah Brunner \& Suddarth. Edisi VIII. Alih Bahasa Kuncara et al. Jakarta: ECG, 2010.

Triyanto, Endang. Pelayanan Keperawatan bagi Penderita Hipertensi Secara Terpadu. Yogyakarta: Graha IImu, 2014.

Udjianti, Wajan Juni. Keperawatan Kardiovaskular. Jakarta: Salemba Medika, 2010.
Murni. "Efektivitas Terapi Musik Klasik dalam Menurunkan Tekanan Darah pada Penderita Hipertensi". 2010. Diakses tanggal 19 Desember 2014.

Suherly, Muhammad, Ismonah dan Wulandari Meikawati. "Perbedaan Tekanan Darah pada Pasien Hipertensi Sebelum dan Sesudah Pemberian Terapi Musik Klasik di RSUD Tugurejo Semarang". 2013. Diakses tanggal 19 Desember 2014.

1 Dosen AKPER Panti Kosala

Surakarta

2 Mahasiswa AKPER Panti Kosala Surakarta 